\title{
Recycling of iron-containing deposits - the main way to increase the efficiency of water- protective measures on the territory of the Tom lower course
}

\author{
Viktor K. Popov ${ }^{1}$, Elena Yu. Pasechnik ${ }^{1, *}$, and Anna Karmanova ${ }^{1}$ \\ ${ }^{1}$ Tomsk Polytechnic University, 30 Lenin Avenue, Tomsk, 634050, Russia
}

\begin{abstract}
The paper presents the investigation of iron-containing deposits at water treatment in the Tomsk water supply intake. The chemical composition of the waters facilitates the formation of deposits in a large amount on the territory of the Tom lower course. A large ground water deposit is located here, and it is used for Tomsk water supply. Currently, the deposit obtained at water treatment is discharged in the Kislovka, and this practice causes a serious environmental problem. The ways of deposit usage are offered in the paper, which will sufficiently increase environmental protection measures on the territory of the Tom lower course.
\end{abstract}

\section{Introduction}

The high level of surface water contamination [1, 2, 3] promotes transition to underground water supply systems. In Tomsk region the use of ground waters is also in priority for drinking water supply. Tomsk is provided with drinking water due to reserves of a major drinking ground water deposit, which is called «Tomskoye». It is located in Tomsk region, in the northern part of the Ob-Tom interstream area [4].

A water supply intake started its operation in December, 1973. Currently, it consists of 198 operating wells arranged in three of its lines. The water supply intake gets out ground waters from the aquifer system in Paleogene sediments of «Tomskoye» deposit in the volume of 149.32 thousand $\mathrm{m}^{3} /$ day $[5,6]$. The same aquifer system is exploited by 2 water supply intakes of Seversk located on the bank of the Tom. Their productivity is 60 thousand $\mathrm{m}^{3} /$ day.

However, the use of deep-well water cannot solve the task of providing the population with the water of satisfactory quality.

\footnotetext{
* Corresponding author: paseyu@yandex.ru
} 


\section{Geology and Hydrogeology}

The considered area is situated at the joint of two major hydrogeological structures - a Kolyvan-Tomsk bow area and a West-Siberian artesian aquifer basin. It is located in a forest-taiga landscape zone with a normal humidity and heat provision, with favourable physical and geographical conditions for infiltration recharge of ground waters. Within the boundaries of Tomsk and Novosibirsk regions the Kolyvan-Tomsk bow area is called «Tomsk downfold» («Tomsky progib»). It is formed with terrigenous flysh deposits of Devonian-Carbonic periods. Its formation is complicated by the presence of a major folding in the shape of anticlinal and synclinal folds divided by the system of longitudinal thrust and upthrust faults of the early-late folded deposit.

The studied region is included in the outer area of the West-Siberian artesian basin, where all the aquifer systems participate in intense water exchange and contain infiltration waters, which have similar hydrogeochemical characteristics. Only in the northern part of the interstream area the waters of chalk and Paleozoic deposits are located in the zone of delayed water exchange.

Three hydrogeological complexes are distinguished within the boundaries of the $\mathrm{Ob}$ Tom interstream area and the right-bank Tom, according to structural and geologic demarcation of the West-Siberian artesian basin: water drive systems of fault waters on the Paleozoic basement, a water drive system of chalk deposits (low and upper hydrogeological levels), water drive systems of Paleogene and Quaternary deposits (an upper hydrogeological level) [7].

\section{Chemical composition of ground waters}

The ground waters of the area are divided into four types (according to S.A. Shcherbakov, in descending order): hydrocarbonate calciferous-magnesium, hydrocarbonate sodium, hydrocarbonate-chloride sodium, and chloride sodium one. They are nitrogen-carbonate in composition, with oxygen to $1-3 \mathrm{mg} / \mathrm{L}[7,8,9]$. Table 1 shows the chemical composition of ground waters on the territory of the Ob-Tom interstream area. Within the boundaries of a hydrogeochemical section a general zonal sequence is observed. It is caused by the change of water exchange conditions from active flushing to relatively delayed one.

Table 1. Composition and characteristics of ground waters on the territory of the Ob-Tom interstream area

\begin{tabular}{|c|c|c|c|c|c|c|}
\hline \multirow{2}{*}{$\begin{array}{l}\text { Determined } \\
\text { indicator }\end{array}$} & \multirow{2}{*}{$\begin{array}{l}\text { Units of } \\
\text { measu- } \\
\text { rement }\end{array}$} & \multirow[t]{2}{*}{ MAC } & \multicolumn{4}{|c|}{ Water characteristics } \\
\hline & & & $\begin{array}{c}\text { Waters of } \\
\text { Neogene } \\
\text { Quaternary } \\
\text { deposits }\end{array}$ & $\begin{array}{c}\text { Waters of } \\
\text { Paleogene } \\
\text { deposits }\end{array}$ & $\begin{array}{c}\text { Waters of } \\
\text { chalk } \\
\text { deposits }\end{array}$ & $\begin{array}{c}\text { Waters of } \\
\text { Paleozoic } \\
\text { deposits }\end{array}$ \\
\hline Ammonium & $\mathrm{mg} / \mathrm{L}$ & 2 & $0.1 \ldots 2.63$ & $0.5 \ldots 2.3$ & $0.02 \ldots 1.50$ & $0.16 \ldots 1.85$ \\
\hline Nitrates & $\mathrm{mg} / \mathrm{L}$ & 45 & $0.00 \ldots 4.65$ & $0.00 \ldots 0.14$ & $0.00 \ldots 1.00$ & $0.005 \ldots 4.4$ \\
\hline Nitrites & $\mathrm{mg} / \mathrm{L}$ & 3 & $0.00 \ldots 0.10$ & $0.00 \ldots 0.05$ & $0.00 \ldots 0.04$ & $0.001 \ldots 0.075$ \\
\hline Iron & $\mathrm{mg} / \mathrm{L}$ & 0.3 & $0.4 \ldots 16.5$ & $0.9 \ldots 10$ & $1.5 \ldots 10$ & $0.93 \ldots 16.8$ \\
\hline Manganese & $\mathrm{mg} / \mathrm{L}$ & 0.1 & $0.5 \ldots 1.25$ & $0.2 \ldots 0.4$ & $0.1 \ldots 8.0$ & $0.1 \ldots 30.26$ \\
\hline Mineraliztion & $\mathrm{g} / \mathrm{dm}^{3}$ & 1 & $0.15 \ldots 0.60$ & $0.25 \ldots 0.50$ & $0.31 \ldots 0.58$ & $0.13 \ldots 4.58$ \\
\hline Hardness & $\begin{array}{l}\mathrm{mmol}- \\
\mathrm{eq} / \mathrm{dm}^{3}\end{array}$ & 7 & $0.4 \ldots 7.0$ & $1.3 \ldots 7.2$ & $3.65 \ldots 18.4$ & $5.5 \ldots 8.35$ \\
\hline Sulphates & $\mathrm{mg} / \mathrm{L}$ & 350 & $0.0 \ldots 14.0$ & $0.00 \ldots 4.0$ & $0.0 \ldots 3.5$ & \\
\hline Fluorides & $\mathrm{mg} / \mathrm{L}$ & 1.5 & $0.15 \ldots 0.50$ & $0.20 \ldots 0.60$ & 0.45 & $0.10 \ldots 0.30$ \\
\hline Chlorides & $\mathrm{mg} / \mathrm{L}$ & 500 & $0.51 \ldots 16.70$ & $0.72 \ldots 17.70$ & $3.9 \ldots 1874$ & $0.47 \ldots 12.50$ \\
\hline
\end{tabular}




\begin{tabular}{|c|c|c|c|c|c|c|}
\hline Oxidation & $\mathrm{mg} / \mathrm{L}$ & 5 & -- & $2.0 \ldots 5.0$ & $3.2 \ldots 3.84$ & $0.7 \ldots 3.6$ \\
\hline
\end{tabular}

According to the data [6], the waters of the Palogene horizon used for water supply change in their chemical composition from South to North from hydrocarbonate calciferous-magnesium with the mineralization of $0.13-0.34 \mathrm{~g} / \mathrm{dm}^{3}$ to chloride sodium with the mineralization of $1.85-4.58 \mathrm{~g} / \mathrm{dm}^{3}, \mathrm{pH}$ and $\mathrm{Eh}$ are within the limits of $6.8 \ldots 7.6$ and $+90 \ldots+120 \mathrm{mV}$, respectively. Under the conditions of relatively delayed water exchange, iron is easily decomposed from the rocks, forming $\mathrm{Fe}^{2+}$ ions. The waters of a Palogene water-bearing stratum are enriched with iron in the amount of $0.9-10 \mathrm{mg} / \mathrm{L}$.

The following scheme of water treatment from iron is approved at designing the underground water supply intake. The water delivered by artesian wells passes to aerators, where it is enriched with oxygen through water outpouring from the pipe located under the chamber surface. Then, water passes from aerators by gravity to rapid filters, where it is treated from iron, and it transits into the reservoir for pure water via a clarified water pipe line. There out, using the secondary pumps, it is supplied in pure water lines to the third pump stations and, finally, it is pumped into the water supply system of Tomsk. In order to decontaminate this water, its disinfection with sodium hypochlorite is provided.

Several water samples were taken in the Tomsk water supply intake at different stages of water treatment (Table 2). The analyses are performed at the accredited laboratory of Scientific and Research Centre «Water» (TPU). The water is characterized by a high concentration of iron and silicon. In the process of water treatment $\mathrm{pH}$ increases, the concentration of chlorine, hydrocarbonate and nitrates grows, and the decrease in the majority of indicators is observed. Besides the above mentioned components (iron and silicon), the other indicators from the operating wells of the Tomsk underground water supply intake do not exceed maximum admissible values.

Table 2. Chemical composition of waters at different stages of water treatment in Tomsk underground water supply intake

\begin{tabular}{|c|c|c|c|c|c|}
\hline Indicators & $\begin{array}{c}\text { Units of } \\
\text { measu- } \\
\text { rement }\end{array}$ & $\begin{array}{c}\text { Norms in } \\
\text { SanRaN } \\
2.1 .4 .1074-01\end{array}$ & $\begin{array}{c}\text { Ground } \\
\text { water }\end{array}$ & $\begin{array}{c}\text { System of } \\
\text { reuse }\end{array}$ & $\begin{array}{c}\text { Water passed } \\
\text { through filter } \\
\text { treatment }\end{array}$ \\
\hline $\mathrm{pH}$ & $\mathrm{pH}$ & $6-9$ & 6.8 & 6.38 & 7.14 \\
\hline $\mathrm{CO}_{2}$ & $\mathrm{mg} / \mathrm{L}$ & & 41.4 & 92.4 & 29.5 \\
\hline $\mathrm{CO}_{3}{ }^{-}$ & $\mathrm{mg} / \mathrm{L}$ & & $<3$ & $<3$ & $<3$ \\
\hline $\mathrm{HCO}_{3}^{-}$ & $\mathrm{mg} / \mathrm{L}$ & & 329 & 354 & 369 \\
\hline $\mathrm{SO}_{4}{ }^{-2}$ & $\mathrm{mg} / \mathrm{L}$ & 500 & 2.29 & 3.73 & 2.07 \\
\hline $\mathrm{Cl}^{-}$ & $\mathrm{mg} / \mathrm{L}$ & 350 & 7.98 & 13.45 & 10.4 \\
\hline Total hardness & $\mathrm{mg} / \mathrm{L}$ & 7.0 & 5.20 & 5.60 & 5.82 \\
\hline $\mathrm{Ca}^{2+}$ & $\mathrm{mg} / \mathrm{L}$ & & 80 & 80 & 87.2 \\
\hline $\mathrm{Mg}^{2+}$ & $\mathrm{mg} / \mathrm{L}$ & & 14.6 & 19.56 & 17.8 \\
\hline $\mathrm{Na}^{+}$ & $\mathrm{mg} / \mathrm{L}$ & & 13.9 & 16 & 14 \\
\hline $\mathrm{K}^{+}$ & $\mathrm{mg} / \mathrm{L}$ & 200.0 & 0.72 & 1.04 & 0.79 \\
\hline $\mathrm{Fe}^{\text {oбщ }}$ & $\mathrm{mg} / \mathrm{L}$ & 0.3 & 2.2 & 7.5 & 0.075 \\
\hline Mineralization & $\mathrm{mg} / \mathrm{L}$ & 1000 & 448.5 & 487.8 & 501.3 \\
\hline $\begin{array}{c}\text { Permanganate } \\
\text { oxygen demand }\end{array}$ & $\mathrm{mgO} / \mathrm{dm}{ }^{3}$ & 5.0 & 1.5 & 2.22 & 0.98 \\
\hline $\begin{array}{c}\text { Electric } \\
\text { conductivity }\end{array}$ & $\mathrm{mS} / \mathrm{cm}$ & & 0.487 & 0.51 & 0.559 \\
\hline $\mathrm{NH}_{4}^{+}$ & $\mathrm{mg} / \mathrm{L}$ & 2.0 & 0.85 & 0.0029 & 0.22 \\
\hline $\mathrm{NO}_{2}^{-}$ & $\mathrm{mg} / \mathrm{L}$ & 3.0 & $<0.02$ & $<0.02$ & $<0.02$ \\
\hline
\end{tabular}




\begin{tabular}{|c|c|c|c|c|c|}
\hline $\mathrm{NO}_{3}{ }^{-}$ & $\mathrm{mg} / \mathrm{L}$ & 45 & 0.1 & 2.23 & 0.98 \\
\hline $\mathrm{PO}_{4}{ }^{3-}$ & $\mathrm{mg} / \mathrm{L}$ & & 0.57 & & 0.121 \\
\hline $\mathrm{Si}$ & $\mathrm{mg} / \mathrm{L}$ & 10.0 & 12.06 & 11.94 & 12.2 \\
\hline $\mathrm{J}$ & $\mathrm{mg} / \mathrm{L}$ & & 0.15 & 0.083 & 0.04 \\
\hline
\end{tabular}

Also, the results on rare-earth elements in ground waters were obtained. It can be concluded that water treatment gives positive results for such elements as gadolinium, dysprosium, and erbium (Table 3 ).

Table 3. Content of rare-earth elements in ground waters

\begin{tabular}{|c|c|c|c|c|}
\hline \multirow{2}{*}{ Elements } & \multirow{2}{*}{$\begin{array}{c}\text { ICP MS } \\
480 \mathrm{X}, \\
\mathrm{mg} / \mathrm{L}\end{array}$} & $\begin{array}{c}\text { Water passed } \\
\text { through filter } \\
\text { treatment }\end{array}$ & System of reuse & Ground waters \\
\cline { 3 - 5 } & 0.00005 & 0.0000015 & 0.000015 & 0.0000017 \\
\hline $\mathrm{La}$ & 0.00005 & 0.0000007 & 0.000025 & 0.0000006 \\
\hline $\mathrm{Ce}$ & 0.00005 & $<0.0000005$ & $<0.0000005$ & $<0.0000005$ \\
\hline $\mathrm{Pr}$ & 0.00005 & $<0.0000005$ & 0.0000088 & $<0.0000005$ \\
\hline $\mathrm{Nd}$ & 0.00005 & 0.0000024 & 0.0000031 & 0.0000023 \\
\hline $\mathrm{Sm}$ & 0.00005 & $<0.0000005$ & $<0.0000005$ & $<0.0000005$ \\
\hline $\mathrm{Eu}$ & 0.00005 & $<0.0000005$ & 0.0000052 & 0.0000011 \\
\hline $\mathrm{Gd}$ & 0.00005 & $<0.0000005$ & $<0.0000005$ & $<0.0000005$ \\
\hline $\mathrm{Tb}$ & 0.00005 & $<0.0000005$ & 0.0000051 & 0.0000014 \\
\hline $\mathrm{Dy}$ & 0.00005 & $<0.0000005$ & $<0.0000005$ & $<0.0000005$ \\
\hline $\mathrm{Ho}$ & 0.00005 & $<0.0000005$ & 0.0000041 & 0.0000011 \\
\hline $\mathrm{Er}$ & 0.00005 & $<0.0000005$ & $<0.0000005$ & $<0.0000005$ \\
\hline $\mathrm{Tm}$ & 0.00005 & $<0.0000005$ & $<0.0000005$ & $<0.0000005$ \\
\hline $\mathrm{Yb}$ & 0.00005 & $<0.0000005$ & $<0.0000005$ & $<0.0000005$ \\
\hline $\mathrm{Lu}$ & & \multicolumn{3}{|c|}{} \\
\hline
\end{tabular}

ICP MS 480X - determination of elemental composition for natural and drinking waters with mineralization to $2000 \mathrm{mg} / \mathrm{L}$.

\section{Iron-containing deposits of water treatment}

Ferrous iron is stable at lack of dissolved oxygen and other oxidizing agents in ground waters. In ground waters carbon dioxide is dissolved in large amounts, therefore, probably, the main form of iron presence in ground waters is the solution of iron hydrocarbonate (II) $-\mathrm{Fe}\left(\mathrm{HCO}_{3}\right)_{2}$.

In the process of ground water aeration a large amount of deposits is precipitated in the iron removal station in Tomsk, $100-150 \mathrm{~kg}$ /day. To determine the deposit composition several water samples from filters were taken in the water supply intake. Investigations were conducted in the scientific laboratory of optical and electronic microscopy of International Innovation Research and Education Centre «Uranium geology» based on the Department of Geoecology and geochemistry (TPU). They were carried out using a diffractometer Bruker D2 Phaser. The method of X-ray diffractometry allowed detecting $\mathrm{SiO}_{2}$ in deposits. It was difficult to identify the other minerals using this method.

The method of atom-emission photocolorimetric analysis as well as flame photometry according to [10] showed the following results, in \%: iron -30.3 , manganese -4.5 , silicon -4.0 , calcium - 1.0, magnesium and aluminum - a tenth of per cent, copper, barium, silver, 
chrome - a hundredth of per cent, boracium, titanium, lead, tin, strontium, lutetium, europium - a thousandth of per cent. In addition, losses on calcination are of $27-29 \%$.

\section{Problem of iron-containing deposit recycling}

Formation of a larger amount of deposits at water treatment causes a serious environmental problem, which has arisen from the very beginning of water supply intake operation, and it has not been solved yet. Currently, the deposit is discharged together with untreated waste waters in the river Kislovka. This water course is flowing through a specially protected natural reservation in the zone of the Ob-Tom interstream area, and this fact makes the environmental issue of this region even worse.

Deposit recycling through underground disposal seems also to be impossible as far as more and more new territories are required, which need remediation. Dry deposit is characterized by higher dusting, and, if the technology is not maintained, the danger arises to pollute the atmosphere and stuff vast territories with iron-containing dust.

The method of wet deposit briquetting with its further drying and use in metallurgy is economically irrational, in comparison with the use of ore.

In the current settings, it is possible to reprocess iron-containing deposits into chemical agents, and to use them as colouring agents and building materials.

\section{Conclusion}

Features of the hydrogeological conditions and geological structure in the Ob-Tom interstream area facilitate the formation of ground waters with a high iron content. In the iron removal station the large amount of iron-containing deposits is formed in the process of aeration, and its recycling becomes a serious scientific problem. It is possible to implement some world practices in the Tomsk water supply intake: to use iron-containing deposits for production of chemical agents, colouring agents, and building materials. The solution of the problem concerning the recycling of iron-bearing deposits at water treatment will allow improving the environment on the territory of the Tom lower course and increasing the efficiency of present water-protective measures.

\section{Acknowledgements}

The reported study was funded by RFBR according to the research project No. 16-3500429 мол_а.

\section{References}

1. V.A. Zemtsov, O.G. Savichev, Resources, regime and quality of surface waters in the Ob River basin: history, current state and problems of research. International Journal of Environmental Studies. 72(3). 386-396, (2015).

2. S.L. Shvartsev, N.M. Rasskazov, O.G. Savichev, Contents and migration forms of elements in natural waters of the mid-Tom' basin. Geologiya $i$ Geofizika. 12 (1997).

3. O.G. Savichev, I.A. Matveenko, E.V. Ivanova, Conditions of contaminant distribution in the wetland water of Western Siberia (the Russian Federation). IOP Conf. Series: Earth and Environmental Science. 33. 1-6, (2016).

4. Ed. by A.F. Poryadin, V.P. Zinoviev, From a pure spring. Lifetime of Tomsk water pipe-line. 304 (2005).

5. Geo-environment conditions of Tomsk region territory in 2014. Information 
bulletin 20. 84 (2015).

6. V. Lgotin, Y.Makushin, Groundwater monitoring to assess the influence of injection of liquid radioactive waste on the Tomsk public groundwater supply, Western Siberia, Russia. Geological Society Special Publication. 128. 255-264, (1998).

7. V.K. Popov, O.D. Lushevich, V.A. Korobkin et al., Environmental and economic aspects of ground water exploitation in the Ob-Tom interstream area. 174, (2003).

8. E.Y. Pasechnik, Ecological and geochemical conditions of natural waters on the territory of Tomsk (the right-bank Tom): extended abstract of a dissertation for PhD in Geology and Mineralogy. 22 (2010).

9. O. Levina, E.Y. Pasechnik, A.V. Baranova, Changes in Chemical Composition of Natural Waters in Response to Technogenic Load. 10. 137-144, (2014).

10. V.N. Lisetsky, V.N. Bryukhantsev, A.A. Andreichenko, Water treatment deposit recovery and recycling in Tomsk water supply intakes. 164 (2003). 